\title{
Fanconi Anemia Group D2 Protein
}

National Cancer Institute

\section{Source}

National Cancer Institute. Fanconi Anemia Group D2 Protein. NCI Thesaurus. Code C85886.

Fanconi anemia group D2 protein (1471 aa, $166 \mathrm{kDa}$ ) is encoded by the human FANCD2 gene. This protein plays a role in chromosome pairing during meiosis, repair of DNA double-strand breaks and cell cycle checkpoint regulation. 